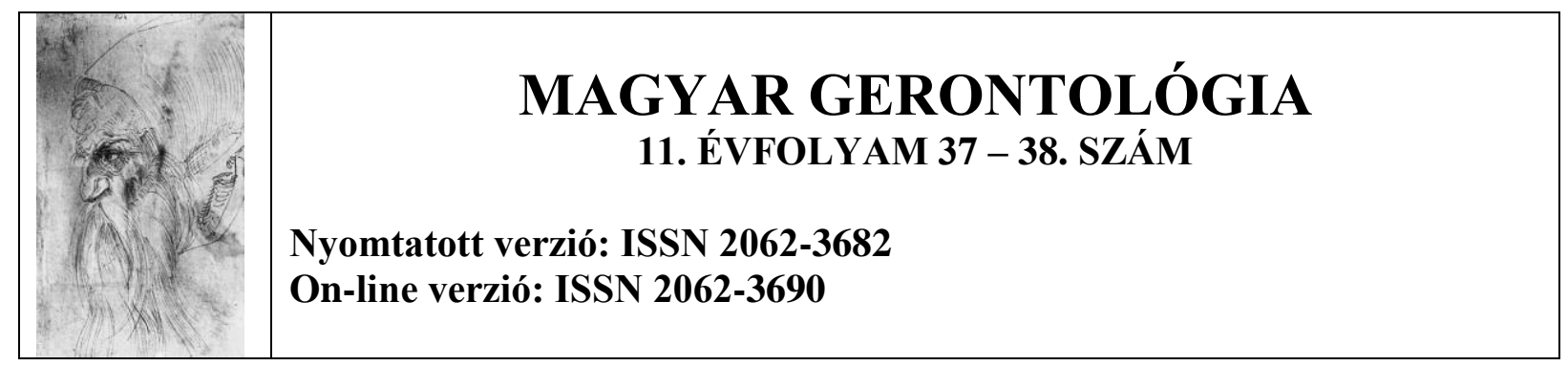

\title{
IDŐSGONDOZÁS AZ ELLÁTÓRENDSZEREN KÍVÜL: A CSALÁDI GONDOZÓK KIHÍVÁSAI
}

dr. Tróbert Anett Mária $\mathrm{PhD}^{1}-$ dr. Széman Zsuzsa $\mathrm{PhD}^{2}$

\author{
${ }^{1}$ Semmelweis Egyetem Egészségügyi Közszolgálati Kar, Mentálhigiéné Intézet \\ ${ }^{2}$ Semmelweis Egyetem Egészségügyi Közszolgálati Kar, Mentálhigiéné Intézet \\ Levelező szerző: \\ Tróbert Anett Mária PhD \\ Semmelweis Egyetem Egészságügyi Közszolgálati Kar \\ Mentálhigiéné Intézet \\ 1089 Budapest, Nagyvárad tér 4. \\ tel: 36 (1) 266-0878 \\ mail: trobert.maria@public.semmelweis-univ.hu
}

\section{Összefoglalás}

A tartós gondozási rendszer túlterheltsége miatt egyre fontosabb a családi gondozók szerepe az idősellátásban. A gondozás felvállalása azonban jelentős megterheltséggel jár, melynek számos negatív következménye lehet a családi gondozók családi élete, munkavállalása, testilelki egészsége tekintetében. A jelenlegi hazai ellátórendszer kizárólag a gondozottak szükségleteire fókuszál, a családi gondozók támogatására még nincsenek szolgáltatások. Tanulmányunkban 10, családi gondozóval készített mélyinterjú tükrében ismertetjük legfontosabb nehézségeiket.

Kulcsszavak: tartós gondozás, szociális ellátórendszer, családi gondozók, megterheltség

ELDERLY CARE OUT FROM THE CARE SYSTEM: THE CHALLENGES OF FAMILY CARERS 


\begin{abstract}
The overburdened long term care system increases the role of family carers in taking care of older adults. Undertaking the role of care put a great burden to family carers and cause many negative effects to the family roles, the field of employment and to the carers' personal physical and mental health too. The formal care system solely focuses for the need of care receivers and hardly find services targeted to family carers. This study, using the analisis of ten family caregiver interviews, overlaps the main difficulties they are facing.
\end{abstract}

\title{
Keywords: long term care, social care services, family carers, burden
}

\section{Bevezetés}

A társadalom elöregedése számos gazdasági-társadalmi problémát indukál. A jelenség egyik legfontosabb szegmense a tartós gondozási rendszer alkalmazkodási nehézsége: nemcsak a fenntarthatóság és az ellátás minőségének biztosítása válik kérdésessé (EK TG 2008), fokozódnak a strukturális problémák is. Egyre nehezebbé válik például a szolgáltatásokhoz való egyenlö hozzáférés biztosítása - a vidéki területek, az alacsony jövedelemmel rendelkezők, és a speciális ellátást igénylők marginalizálódnak (EUT SZV 2014). Az egészségügyi és a szociális ellátórendszerek elszigeteltsége, az integrált tartós gondozási rendszer hiánya pedig gyakran lehetetlenné teszi a minőségi szakmai idősellátást. (Széman és Tróbert 2017/1,2, Tróbert és Széman 2018) Mindezzel együtt erösödik az idős beteget gondozó családtagok terheltsége, azonban a családi gondozók megfelelő támogatása nem biztosított. Az ellátórendszer megújítása elkerülhetetlen.

Az Európai Unió által támogatott MoPAct nemzetközi projekt (Mobilising of the Potential of Active Ageing in Europe/Az aktív idősödés lehetőségeinek mobilizálása az Európai Unióban) tartós idősgondozással foglalkozó munkacsoportjának célkitüzése volt, hogy feltárja az idősgondozás jövőbeli potenciáljait kiemelt szakértők és fókuszcsoportokba beválasztott szakértők (pl. önkormányzati és egyházi gondozási központok vezetői, vezető munkatársak, falugondnok) véleményeinek elemzésével. A kutatásban résztvevő országokban (Németország, Ausztria, Olaszország, Románia, Észtország, Magyarország) városi és vidéki régiókban 2-5 szakértői interjút továbbá 2-3 fókuszcsoportos interjút készítettek. A fókuszcsoport tagjai különböző szférában dolgozó (önkormányzati, egyházi, nonprofit, magán szféra) szakemberek voltak. Mind a szakértői mind a fókuszcsoportos interjúk célja volt, hogy 
a szociális ellátórendszer problémáinak feltárása után olyan megoldásokat keressen, amelyek lehetővé teszik a rendszerek megújhodását, innovatív irányú elmozdulását. A fentiek mellett a kutatás alapvető részét képezték a jó példák felkutatása és fenntarthatóságuk korlátainak illetve „hajtóerejének” analizálása. Az ezekre vonatkozó eredmények korábban már publikálásra kerültek (Széman és Tóbert 2017/1, 2017/2) illetve munkaanyagokban megtalálhatóak a projekt publikációi közt (Schulmann és mtsai 2014, 2015). Magyarországon azonban a fókuszcsoportos adatok elemzése alapján olyan problémák is felmerültek, amelyek mélyebb megismeréséhez szükségesnek tűnt a gondozást végző családtagokkal is interjút készíteni. Összesen 10 családtag meginterjúvolására került sor (2015-2016). Tanulmányunkban a szakértői és fókuszcsoportos interjúk során elhangzott, családi gondozókhoz köthető nehézségek ismertetését követően a családi gondozókkal készült mélyinterjúk (Tróbert és Széman 2016) legfontosabb tanulságait mutatjuk be a fókuszcsoportos és szakértői interjúk idevonatkozó eredményeit figyelembe véve.

\section{A családi gondozók legfontosabb nehézségei a szakértők szemével - fókuszcsoportos és szakértői interjúk}

A mélyinterjúkat megelőző két fókuszcsoportos és két szakértői interjúban - mindkét típusú interjúzás Budapesten illetve egy vidéki, tanyavilággal rendelkező helyszínen, nyíregyházi mintában zajlott - a következő, családi gondozást érintő problémák merültek fel (Tróbert és Széman 2015).

\section{Növekvö gondozási igények - a prevenció szükségessége}

Az első fókuszcsoportban, Nyíregyházán az idősödéssel kapcsolatos lényegi kérdésként jelent meg az aktív idősödés kultúrájának előmozdítása, és ezzel párhuzamosan a generációk közötti kapcsolatok erősítése, például az infokommunikációs készségek fejlesztésével az idősek körében. A Skype használata például jelentősen hozzájárulhat az idősek kapcsolathálójának fenntartásához, így jól-létének, lelki egészségének megőrzéséhez is.

Az idősödés folyamata számos kihívást támaszt az idősödő ember és családja részére is - a sikeres megküzdést jelentős mértékben elősegítené a szakszerü mentálhigiénés segítség nyújtása az idősek és családtagjaik részére már a szolgáltatások igénybe vétele előtt, és a házi segítségnyújtáshoz kapcsolódva is, hogy az idősek „másképp” öregedhessenek meg.

Ezzel együtt, a második, budapesti fókuszcsoport résztvevői szerint szükséges lenne a fiatalok felkészítése az "öregekre". Ez nem pusztán a kötelességtudat kimüvelését kívánná meg, hanem az időskorhoz való viszonyulás tudatos formálását is. 


\section{A lehető legtovább a saját otthonban élni - a fenntartható otthoni ápolás hiánya}

Valamennyi interjú során elhangzott, hogy az idősek saját otthonában történő ápolását nem csak a költséghatékonyabb ellátási forma miatt lényeges előtérbe helyezni, hanem azért is, mert a szakértők szerint az idősek a lehető legtovább saját környezetükben szeretnének maradni. A bentlakásos intézménybe kerülés kitolásához azonban a preventív szemlélet gyakorlati alkalmazásán túl meg kell teremteni a minőségi otthoni ápolás jelenleg hiányzó feltételeit.

Családi gondozók megterheltsége, intézményi támogatás - a megfelelö szolgáltatások

\section{hiánya}

A családi gondozók megterheltségének témaköre különösen a szakértői interjúkban volt hangsúlyos.

Mivel az ellátórendszer kapacitása nem növekszik az igényekkel párhuzamosan, egyre több teher hárul az informális gondozókra, viszont nincs őket támogató szolgáltatás. A hozzátartozó ápolásának felvállalása esetén fontos problémaként jelentkezik a munka és a gondozás összeegyeztethetetlensége. A gondozási feladat gyakran csak a pihenőidő rovására végezhető. A megterheltség ebből fakadóan is jelentős, és sok esetben nincs feltöltődést biztosító segítség - pl. a beteg felügyelete nem megoldható.

Igen lényeges lenne tehát az informális gondozók támogatási rendszerének kiépítése, a hiányzó szolgáltatások kifejlesztése (például hétvégi gondozás, a pihenést lehetővé tevő szolgáltatások kialakítása), emellett a rugalmas munkaidő biztosítása, a gondozás megfelelő anyagi támogatása (az igényelhető ápolási díj nagyon alacsony) is elengedhetetlen. A személyes, mentálhigiénés támasz szintén szükséges a gondozás hosszú távú felvállalásához, azonban az ellátórendszerben jelenleg egyáltalán nem elérhető. A megterheltség, kiégés gyakorisága a családi gondozók körében szükségessé teszi az igényeknek megfelelő hatékony támogató rendszer mielőbbi kialakítását.

A budapesti fókuszcsoportban kiemelték, hogy már a meglévő szolgáltatások könnyebben elérhetővé tétele is támogatná a családokat, például a nappali intézménybe történő szállítás megoldása. Számos szolgáltatás hiányzik azonban, például a 4 órán túli ellátásra szorulók otthoni ellátásának segítése, a családok tehermentesítése (pl. "Dédi sitter" programmal), a hatékony prevenció, vagy a szükségletekhez alakított nappali ellátás.

\section{Hozzátartozók együttmüködése - a partneri együttmüködés hiánya}

Hangsúlyozni kell, hogy településtípustól függetlenül mindkét fókuszcsoportban jelentős hiányosságként jelent meg az ellátottak hozzátartozóinak információval történő ellátása. A 
megfelelő információk hiánya miatt a hozzátartozók gyakran nem jutnak hozzá az igényelhető szolgáltatásokhoz sem.

A már igényelt szolgáltatások esetén a hozzátartozókkal való együttmüködés ugyanolyan lényeges lenne, mint az intézmények közötti, azonban ez sokszor azért nem valósulhat meg, mert nincsen partneri viszony a hozzátartozókkal (mindkét fél részéről előfordulnak hiányosságok).

\section{A családi gondozók nehézségei a mélyinterjúk szerint}

A hozzátartozók szakértői és fókuszcsoportos interjúkban kirajzolódó nehézségei a mélyinterjúkban árnyaltabban és mélyebben jelentek meg. Az információhiány nem pusztán a szolgáltatások ismeretének hiányaként, hanem több rétegü ápolási kompetencia-hiányként manifesztálódott. A gondozás és munka összeegyeztethetetlensége mellett megjelent a munkahelyi kiégés veszélye, de a munkahely pozitív szerepe is. Új dimenzióként mutatkozott a gondozó saját családi életének gondozási feladattal összefüggő akadályozottsága, sérülékenysége. A mentálhigiénés támogatás igénye azonban nem csak ebben a dimenzióban, hanem a szerepkonfliktusok és megküzdési nehézségek kapcsán is előtérbe került. Az erőforrások tekintetében a támogató szolgáltatások hiányán túl megmutatkozott a spirituális erőforrások pozitív szerepe. Az ellátórendszer hiányosságai mellett pedig láthatóvá vált a szolgáltatásokkal szembeni tartózkodás néhány motívuma. Az alábbiakban közölt interjúrészleteknél a teljes anonimitás érdekében a keresztnevek kezdőbetűit megváltoztattuk.

\subsection{A gondozáshoz szükséges ismeretek hiánya}

\section{Információhiány}

Nem csak a rászoruló idősek nem tudnak az elérhető szolgáltatásokról, hanem sok esetben az őket gondozó családtagok sem. Nem kapnak megfelelő tájékoztatást sem a háziorvostól, sem a kórházaktól.

A kórházi ellátást követően a betegek családtagjai gyakran magukra maradnak a problémákkal, mert az egészségügyi rendszer és a szociális ellátások közötti kapcsolat nem biztosított. (Az egyik interjúalany pl. egy rádiómüsor kapcsán lett figyelmes arra, hogy édesanyja ápolása miatt anyagi támogatásban részesülhetne - ez alapján kérvényezte a juttatást.) Az orvosok és a szociális szakemberek között legtöbbször nincsen kapcsolat, az információkat a családtagok közvetítik. 
Az ismeretek hiánya sokszor az alapvető, szolgáltatásokkal kapcsolatos információk hiányát jelenti, ami különösen súlyos problémát okoz egy már eleve hátrányos helyzetü, pl. munkanélküli gondozó esetében. Az egyik, munkaerőpiacról kiszoruló családtagnak fel kellett vállalnia egy rendkívül súlyos gondozást anélkül, hogy tisztában lett volna az oot megillető, helyzetét némileg megkönnyítő szociális juttatással. Ez nemcsak az információhiányt mutatja, de rávilágít a munkaerőpiac, a szociális és egészségügyi ellátórendszer valamint a közigazgatás összehangolatlanságára, valamint a rugalmatlanságra is. $\mathrm{Az}$ egyéni helyzet megoldása ugyanis így esetleges, a példában egy ember segítőkészségén múlt.

"Amikor anyu beteg lett, munkanélküli voltam. Nem tudtam, hogy ápolási díjat kaphatok, a gondozó munkatárs hívta fel a figyelmemet a lehetöségre. Már az elejétöl emelt összegüt kaptam, mivel anyut súlyos fogyatékossággal élönek minösitették. Jelenleg kiemelt ápolási dijat kapok. Késöbb tudtam meg, hogy ilyen mértékü betegség esetén a gondozott fogyatékossági támogatást is kaphat - erröl a háziorvos, vagy az ápolási díj igénylésénél az ügyintéző tájékoztathatott volna. Hosszú volt az ügyintézés, rengeteget kellett utánajárnom, de sikerült, és a beadás időpontjáig visszamenöleg megadták a támogatást." (Z., 55 é)

Z. azoknak, akik hasonló helyzetbe kerülnek, mindenekelőtt az informálódást tanácsolja:

"Elöször is, ... informálódjanak, mielött a beteget hazaviszik a kórházból, hogy mi az, amire jogosultak, mit igényelhetnek."

A fenti interjúrészlet alapján újból hangsúlyozni kell, hogy a családtagok gyakran sem a kórházban, sem a háziorvostól nem kapnak megfelelő tájékoztatást az elérhető szociális szolgáltatásokról, és az igényelhető ápolási díjakról. Integrált tartós gondozási rendszer nélkül, az egészségügyi és szociális rendszer közötti kapcsolat hiánya nem csupán a költséghatékonyabb ellátást, a szakmai együttmüködést, így a professzionális, minőségi betegellátást akadályozza, hanem a hozzátartozók megfelelő támogatását is.

\section{Apolási feladatokkal kapcsolatos tudás hiánya}

Mindenkinek nehézséget jelent az ápolási feladatokkal kapcsolatos tudás hiánya. A fekvő beteg mozgatása, mosdatása, szükség esetén etetése csak a megfelelö ismeretek birtokában végezhető biztonsággal és hatékonyan.

"Eleinte technikai nehézségeim voltak.(...) Eleinte szobavécét használtunk - a kiültetés a súlya és a mozgáskorlátozottsága miatt nagyon nehéz volt, ráadásul, mivel vízhajtót is kapott, naponta sokszor kellett megemelnem. (...) 
(Házi segitségnyújtás) dolgozói (...) nagyon sokat segitettek abban, hogy hogyan lássam el a gondozási feladatokat. Megmutatták például, hogyan kell jól emelni, hogy ne eröltessem meg magam. ( ...) Jól jött, hogy éppen azt megelözöen, hogy anyu beteg lett, elvégeztem egy két hónapos házi gondozási tanfolyamot, igy egy egészen kicsi rálátásom volt a helyzetre. Fontos volt, hogy tudtam tanácsot kérni, és megerösitést kaptam, hogy jól csinálom az ápolást. (...)

Az egyik kórházból kijött egy ápoló, ő is adott néhány tanácsot, amit nagyon jól tudtam hasznositani. Aztán sok mindent tapasztalatból tanultam meg." (Z., 55 é)

Kik adhatják át a hiányzó tudást? Súlyos gondozási probléma esetén elengedhetetlen az egészségügyi, gondozási ismeret, s ebben fontos szerepet kap a gyakorlati tudást átadni képes szociális vagy egészségügyi dolgozó, szakember. A dolgozók munkaterhei miatt azonban feltételezhető, hogy ez sok esetben nehezen valósítható meg.

A Magyar Máltai Szeretetszolgálat egyik fontos célkitüzése a gondozó családtag segítése, nem csak a házi segítségnyújtásban tevékenykedő szakemberek személyes tanácsadása, hanem a Szeretetszolgálat innovatív, online támogató portálja, a WebNővér ${ }^{1}$ által is. (vö. Tróbert - Asztalos - Széman 2018)

Ápolási kompetenciák hiányából fakadó problémák

K. arról számolt be, hogy az ápolási kompetenciák hiánya erős szorongást idézett elő benne:

"Az elején nagyon megterhelö volt, féltem, hogy nehogy valamit rosszul csináljak. Nagyon oda kellett figyelni, de hamar rutint szereztem." (K., 52 é)

Az interjúalany alapvetően saját tapasztalataiból építkezve vált gyakorlott gondozóvá. A megerősítés hiányából fakadó aggodalom azonban máig jelentős stressz-forrás számára.

\section{A gondozottat körülvevö környezet-tudás}

A környezet szerepe igen fontos. Z. beszámolójából kiderül, hogy az otthoni gondozási helyzettel nem pusztán a gondozási feladatok megfelelő, biztonságos elvégzését kell a hozzátartozóknak megtanulniuk.

„Jó, ha együtt tudnak gondolkodni arról is, hogy tekintetbe véve a betegszoba adottságait, mi hogyan lesz praktikus. Nem mindegy például, hogyan vannak elrendezve a bútorok, hová lehet tenni a gyógyászati segédeszközöket, hogyan lehet öket a legpraktikusabban használni, hogyan tudjuk a legbiztonságosabban mozgatni a beteget. Én nagyon nehezen szoktam meg, hogy mindenben figyelnem kell arra, hogy

\footnotetext{
${ }^{1}$ www.webnover.hu
} 
anyukám fél oldala, egyik keze és lába nem mozog. Ez például sok rögzitést igényel a mozgatásnál. A tolószék pont befér a fürdöszoba ajtón, most már rutinosan tudom fürdetni is anyukámat. Sok energiát megspórolhatunk, ha ismerjük a "fortélyokat".,"

A gondozás gyakran csak úgy végezhető el, ha a betegszobát (és a lakás beteg által is használt részét) a beteg, és a gondozást ellátó családtag új igényeinek megfelelően átalakítják. Az akadálymentesítés, és a hozzá kapcsolódó szakszerű tanácsadás hazánkban még igencsak gyerekcipőben jár, pedig szükségességét és hatékonyságát Széman Zsuzsa és munkatársai magyar mintán is igen pozitív eredményekkel kutatták. (Széman és Pottyondy 2006)

\section{Komplex tudás}

Van, aki komplex ismereteket igényelne a gondozási helyzettel kapcsolatosan, szakemberek közvetítésével:

"Ha többet tudnék a témáról, az segítene - viszont rossz informálódó vagyok, inkább személyes kapcsolatokban müködik ez, nem tudom könyvböl, vagy netröl kiolvasni. Ha kapnék arról információt, hogy hogyan lehet jól segiteni." (A., 47 é)

A fenti interjúrészletek egyértelmüvé tették, hogy az információ-, tudás-, és kompetenciahiány miatt nélkülözhetetlen a gondozást felvállaló családtagok előzetes képzése, illetve mentorálása. E nélkül a gondozó családtagok magukra maradnak, egyénileg hosszú távon képtelenné válnak a gondozási feladat ellátására. Jelenleg nincsenek a családi gondozók számára kialakított speciális képzések.

\subsection{A gondozási feladat és a családi élet összeegyeztetésének nehézségei}

Valamennyi interjúalany számára központi nehézség a gondozásból fakadó családi konfliktusok kezelése: a gondozó "két tűz közé" kerül. A gondozási helyzet egyéni megélését - vagyis a gondozással járó szubjektív terheket jelentősen növeli a többi családtag negatív hozzáállása, mely interperszonális szinten kapcsolati válságokat, intrapszichésen pedig szorongást, büntudatot okozhat.

\section{Gondozásra fordított ido}

A leggyakoribb probléma a gondozás időigényessége. Egyfelől időt vesz el a gondozott felkeresése, másfelől, a napi, gyakorlati teendőkön túl a mélyebb támogatás biztosításához több órás jelenlét kellene:

"Próbálom minden nap hívni, de sokszor alig hallom, mert kihangositóval beszél igazán beszélgetni nem lehet telefonon. Sokszor, ha odamegyek, elöször a praktikus 
dolgokat mondja, és mélyebb beszélgetésre nincs lehetöség. Az több órás program... " (A., 47 é)

Az idős emberrel való kötetlen beszélgetésre, vagy bármilyen, szellemi foglalkozásra a házi gondozás keretein belül nem jut idő. Pedig a házi segítségnyújtást igénybe vevők legtöbbször elszigeteltek, és a családtagok a saját munkájuk mellett nem tudják feloldani az idős magányát. Sajnos azonban a túlterhelt munkatársak sem tudnak nyugodtan időt szánni az időssel való személyes kapcsolatra.

\section{Család - gondozás - problémák}

A. számára komoly energia saját, és családja határainak védelme:

"Egyrészröl van egy saját családom... Muszáj határokat kitennem, hogy védjem a saját családomat. Nagyon nehéz megtalálni a helyes mértéket. Néha adhatnék többet, néha pedig túl sokat adok."

Emellett az is folyamatos nyomás $\mathrm{A}$. számára, hogy érzi saját családja ellenállását a gondozási helyzettel szemben:

"Nálunk az a nehéz, hogy a férjem annyira nem támogatja ezt a dolgot. Van egy rivalizálás az ö részéröl és a gyerekek részéröl is. Ha kicsit többet vagyok ott, biztos, hogy történik valami otthon, és hívnak, hogy azonnal haza kell jönni. Vagy a gyerekek elkezdik, hogy nem szeretik a nagyit..."

Az idő, és energiatakarékosság miatt szóba kerülhet az együtt lakás is, de ez a lehetőség A. esetében az anyagiak, a gondozott saját otthonához ragaszkodása, valamint a férjével való konfliktusai miatt végül nem valósulhatott meg. A gondozott meg tudná fizetni a minőségi idősotthont, azonban nem nyitott erre a lehetőségre:

" Együtt lakni, nem müködik. (...) Nagyon-nagyon fél attól, hogy egy otthonba bekerül... Ö azt mondja, hogy aki neki ismeröse van, annak nem lett jó megoldás az otthon."

A. számára állandó problémát jelent a folyamatos újratervezés, a családi élet és a gondozás összehangolása:

"Az a megterhelö, hogy merre mennyit fektetek be - nehéz a jó arányokat megtalálni, hogy mennyit kell magamból a gyerekeknek, mennyit a férjemnek, mennyit az anyukámnak adni."

T. is sok időt tölt a szüleivel, és ezt a férje szintén nehezen viseli:

"Ha orvoshoz megyünk, az önmagában fél nap. Heti 2-3-szor megyek hozzájuk, reméljük, hogy ez elég lesz, mert otthon ott van a családom is, a munkám. A férjemnek lelkileg fontos, hogy vele legyek. Az a nehéz, hogy ha otthon van, vele legyek, különben 
pedig a szüleimet is intéznem kell. Most úgy próbálom, hogy heti 2 napon 4-5 órát vagyok a szüleimmel." (T., 50 é)

A gondozási helyzet B. családjában is konfliktusokat okoz:

"A férjem néha vitatkozik, ö nehezebben éli meg." (B., 41 é)

A családi élet és a gondozási szituáció összehangolása sok esetben igen nehéz, pedig a gondozást felvállaló családtag számára a gondozói helyzetből fakadó nehézségekben a család lehetne az egyik legjelentősebb erőforrás. A gondozási helyzetből fakadó, férj és feleség közötti konfliktusok ezen felül a párkapcsolatot is sérülékenyebbé teszik, ami plusz terhet jelent mindkét félnek. Mindez megkívánná a rendszerszemléletü tartós gondozás meghonosítását, és azzal együtt a teljes család mentálhigiénés támogatásának biztosítását.

\subsection{Szerep-konfliktusok}

A segítői helyzet gyakran szerep-konfliktusokat idéz elö, részben a hiányzó segítői kompetenciák, részben az állandó érintettség miatt.

\section{Segítö családtag gyerek szerepben}

A leggyakoribb probléma az, hogy a segítő családtag az otthon töltött időben mintegy újra gyerek szerepbe kerül:

"Nekem egy kicsit nehéz volt visszaköltözni anyukámhoz, az nem volt egyszerü. Fogytam is vagy 6 kilót. De hát biztos mindenkit megvisel, ha fölhívják, hogy anyukája kórházban van." (V., 45 é)

"Nehéz volt az elején hogy nem tudok érdemben segiteni. Meg volt kötve a kezem, mert én otthon gyerek voltam akárhány éves is vagyok." (C., 62 é)

\section{Gondozó családtag és a gondozási teljesítmény}

Különösen nehéz a saját hozzátartozó segítőjévé válni, ha régi, fel nem oldott konfliktusok terhelik a szülő-gyerek kapcsolatot. Nehézséget okoz például, ha a szülő nem tudta "elengedni" a gyermekét. Ekkor a gondozással járó közelebbi viszonnyal az egészséges határtartás is nehezebbé válik. Problémát jelenthet az is, ha a szülő számára a gyermeke teljesítménye nem elég jó - a gondozási helyzetben így állandó elégedetlenséget tapasztal meg, miközben fájdalmat, esetleg büntudatot is okoz gyermekének:

"Anyukám egy kicsit úgy müködik, hogy ő megoldja az én életemet, cserébe én oldjam meg az övét... Nem jutott el arra a pontra, hogy ö ne mások életét akarja megoldani, hanem a saját életét élje. (...) Úgy éli meg, hogy öt nem látogatjuk, pedig hetente kétszer megyek hozzá. Akkor sokszor praktikus dolgokat kér, aztán azt mondja, hogy én nem foglalkoztam vele. Én nyitott lennék arra, hogy akkor azért fizessen meg 
valakit, és én csak vele lennék, de ö ezt nem akarja. (...) Ha tudná elfogadni, ami van, és nem tenne folyton szemrehányást... " (A., 47 é)

"Anyával sokkal nehezebb kijönni. Apa mindent elfogad, jól megvagyunk együtt. Anyával pillanatok alatt összeveszünk... Jó a viszonyunk, de 24 órán keresztül nem tudnék vele egy levegöt szívni. (...) Kifejezetten az nehéz vele szemben, hogy soha nem jó az, amit csinálok. ...Sose vagyok elég jó, és ez baromi nehéz. Mindig görcs van bennem, hogy jaj, most mi lesz. Ez nagyon rossz hatással van rám." (T., 50 é)

\section{Szülői kiszolgáltatottság}

Szintén a szerep-konfliktushoz köthető probléma, hogy a szülő kiszolgáltatottságának megtapasztalása, a testi ápolás megrázó élmény (általában mindkét fél számára):

"Aztán, amikor megérkezett a pelenka, az megdöbbentö élmény volt: lelkileg volt nehéz, hogy anyukámat kell ellátnom. Szembesültem azzal, hogy anyukám, aki pár hónappal ezelött még jól volt, mostantól kezdve teljesen kiszolgáltatott." (Z., 55 é)

A gondozási feladatot Z. különösen akkor érezte megterhelönek, amikor édesanyja részéről ellenállást, a helyzetből fakadó abúzust vagy hálátlanságot tapasztalt:

"...az viszont megterhelt, amikor érzem, hogy 'dafke'. Ez mentális probléma, s ezt higgadtan kezelni nem mindig megy. Amikor teljesen egyértelmü, hogy meg tudná enni, mégsem teszi. (...) Ez a része volt rettenetesen nehéz. (...) Egy őszinte köszönöm nem volt... Nem vörös szönyeget kérek, de egy öszinte köszönömöt. (...) Volt, hogy az ápolók szóltak rá, hogy most már hagyja abba, ahogy beszél velem. (Z., 55 é)

"Nem várok el semmit, egyedül azt, hogy tiszteletet adjon. Ha az nincsen, akkor szoktam leginkább kiakadni (...)" (B., 41 é)

A szerep-konfliktusból adódó nehézségek nemcsak a gondozó családtag, de a gondozott mentálhigiénés támogatásának szükségességét is felvetik. A mentális, pszichés jóllét erősödése mindkét fel részéről hozzájárulhatna a gondozó - gondozott kapcsolat egészségesebbé válásához is.

\subsection{Veszteségek és speciális kihívások}

$\mathrm{Az}$ interjúalanyok többségének nagy terhet jelent a gondozott fokozatos leépülésének látványa. A veszteségekkel való megküzdés, a gondozott halálára, a gyászra való felkészülés komoly kihívás, melyben a családi gondozók legtöbbször magukra maradnak.

Speciális kihívást és különösen nagy megterhelést jelent, ha a gondozott demenciával élö személy. Ekkor a veszteség megtapasztalása minden szinten erősebb, hiszen pl. a gondozott viselkedése megváltozik, a vele való kommunikáció számos esetben teljesen lehetetlenné 
válik. A családi gondozó ekkor folyamatos veszteségélményben, egyfajta megelőlegezett gyászban él:

„Nem elég, hogy egyszer így volt, de hogy ez most már évek óta így tart... (...) ha ö akkor meghalt volna, akkor van egy gyászreakció, eltelik egy év és már rég túl lennék rajta. Így meg igen, egy folyamatos veszteségben vagyok, folyamatos szembesülés..." (G., $46 \dot{e})$

Az interjúalanyok a veszteségekkel és a demenciával kapcsolatban ismételten kiemelték a jelenleg hiányzó mentálhigiénés támogatás igényét és jelentőségét.

\subsection{A tehermentesítés nem megoldott}

Nagy probléma az is, hogy a családi segítők tehermentesítése nem megoldott - az egyik interjúalany évek óta nem pihent hosszabban, mások az intenzív gondozáshoz kötötték a privát életük megszűnését, ismét mások arról számoltak be, hogy egyetlen vágyuk egy kötöttségek nélküli nap:

"2012 óta nem voltam hosszabb szabadságon, csak a kórházi tartózkodása alatt pihentem, és egyszer volt 3 napom... (...) Ez 24 órás elfoglaltság, kiszakadni csak rövid programokra lehet." (Z., 55 é)

"Az embernek (azelőtt) volt egy családja, saját élete. Amikor anyu kijött a kórházból, oda is költöztem, ott voltam vele 2 hónapig. Nem tudott semmit csinálni. " (V., 45 é)

"24 órás felügyeletre szorult, éjjel mindig én voltam vele. 9 hónapon keresztül, fel is kellett kelni hozzá. Napközben pedig munka. (...) A privátszféra abszolút megszünt." (C., 62 é)

"Szerintem nagyon sokan sokra vágyakoznak, nekem elég lenne egy olyan nap is, amikor azt csinálok, amit akarok. Csak ennyi." (K., 52 é)

A tehermentesítés megoldatlansága hosszú távon kimerüléshez vezethet, amely a munkahelyi és a családi életben is komoly veszteségeket okozhat. A számok tükrében a szociális ellátórendszer jelenleg még a gondozottak szükségleteit sem tudja ellátni, nemhogy a támogató családtagok tehermentesítését felvállalni. A preventív szemlélet érvényesülése pedig nagyon fontos lenne, hiszen hosszú távon költségmegtakarítást eredményez nem csak az egészségügyi és szociális ellátórendszer, hanem a munkaerőpiac területén is.

\subsection{Megküzdési nehézségek}

A nehézségekkel való megküzdésben megtartó erő a kapcsolati háló, de kérdés, hogy a meglevő kapcsolati tőkét az egyének valóban képesek-e mozgósítani. 
A legfontosabb erőforrást a legszorosabb kapcsolatok jelentenék, ám éppen ezek terhelödnek leginkább:

"Az hiányzik nagyon, hogy (a férjemmel) nekünk kettönknek legyen idönk. Mindenképp szükségünk lenne több idöre, amikor tudunk beszélgetni, egymással lenni. " (A., 47 é)

T. -nek is a család az első, és lényegesek a barátok, valamint a vallási közösség megtartó ereje:

"Húgom, férjem, gyerekek. Vannak barátaim, de mindig a vallási közösség volt az elsö. Van egy barátnöm, vele néha beszélgetünk." (T., 50 é)

V. számára a férje és a barátai adják a legfontosabb támaszt:

"A férjemmel mindenféleképpen megbeszélem, vele nagyon jól lehet, meg van egy már

22 éve tartó baráti kapcsolat, velük is nagyon jól meg lehet beszélni." (V., 45 é)

Egy másik interjúalany, D., arra a kérdésre, hogy hogyan oldja meg a felmerülő problémákat, és kihez fordul támaszért, azt feleli, mindent családon belül oldanak meg, náluk a tágabb rokoni kör is nagyon összetartó:

"Mindig családon belül. Meg, hogyha segítségre van szükség, rokonság is van, összetartunk, ha bármi probléma van, családon belül zajlik. De sokszor fordulnak hozzánk külsösök is, távolabbi rokonok. Ha bármi gond van, akkor megoldható - pl. fodrászhoz menni, eljönni, stb..." (D., 55 é)

Z. elvált, számára a baráti kapcsolatok jelentősége nagyobb:

"Közel lakik egy gyerekkori barátnöm, sokat találkozunk, sétálunk, kirándulunk - egykét óra alatt bejárjuk a környéket. Fontos, hogy rendszeresen járok színházba, nagyon szeretem a müvészetet. " (Z., 55 é)

$\mathrm{K}$. is rendelkezik erőt adó baráti kapcsolatokkal, viszont a gondozási terheket nem akarja, nem tudja megosztani barátaival:

"Persze vannak barátaim, de sok negatívval nem traktálhatom öket. Nem, valamikor szükségem van arra, hogy elbeszélgessek valakivel, de öt is ,,lehúzom” akkor, azt meg nem akarom. (...) (K., 52 é)

A kapcsolatokban rejlő erőforrás lényeges a megküzdés sikeressége szempontjából, azonban a kapcsolatok ápolására a gondozás miatt kevesebb idő marad. Ez ismét felhívja a figyelmet a gondozást végző családtagok tehermentesítésének és megküzdésben való támogatásának lényeges voltára. 


\subsection{A gondozási feladat negatív hatással lehet a munkavégzésre}

\section{A munka-gondozás összeegyeztethetetlensége-részmunkaidö}

a kérdésre, hogy hogyan hat a gondozási feladat a munkavégzésükre, a gondozók sok esetben munkahelyi nehézségekkel válaszoltak:

"Annyiban volt nehéz, hogy az az idöm volt az iskolára, amit ott töltöttem, egy tanárnak pedig készülnie kell - a lyukasóráimat használtam fel, útközben javítottam..." (A., 47 é)

"...már az első hónap után azt hittem, hogy baj lesz, akármilyen. Vagy, hogy tévedni fogok a munkában. (...) a vége felé volt olyan, hogy az édesanyám hiába kiabált, már nem ébredtem föl. Annyira fáradt voltam." (C., 62)

A munka-gondozás összeegyeztethetetlensége miatt többen a részmunkaidős foglalkoztatást választják, ez pedig könnyebbség ugyan, ám egyben a gondozó jövedelemcsökkenésével jár, a gondozás terhe mellett a gondozó gazdasági helyzetének romlását idézi elő, amit nem kompenzálnak.

Z. egy ideje tulajdonképpen munka helyett látja el a gondozási feladatot:

"2012-ben ismét hosszabb idöt töltött kórházban, ez az időszak is megerösitett, hogy tovább csináljam a gondozást. Egy ideig külsö segitséget is igénybe vettem az éjszakai felügyelethez. Most tulajdonképpen ez a munkahelyem." (Z., 55 é)

D. is az ápolás miatt lett részmunkaidős:

"Nagyon sok volt már, és rosszabb lett az állapota, de változtattam volna amúgy is nem volt kifizetődő. Megérdeklődtem az ápolásit." (D., 55 é)

Munkahelyének közelsége szerencsés helyzetet biztosít:

"Ha bármi van, haza tudok ugrani a munkahelyröl, megoldható."

\section{Munkahely és gondozás összeegyeztethetetlensége - egészségi állapot}

A munkahelyi és gondozási feladatok párhuzamos ellátása legtöbbször nemcsak fizikailag, hanem lelkileg is nagyon megterhelö:

"Az elején nem annyira volt megterhelo", de a végén már nagyon, akkor olyan fáradt voltam, hogy úgy éreztem, el tudnék állva aludni. (C., 62 é)

"Hogy milyen mértékben megterhelö? Van amikor 100\%-ig, van amikor meg abszolút könnyedén veszem az akadályokat. Egyrészt szituációtól függ, meg hogy mennyire vagyok elfáradva. Tehát a többi hozzárakódott dolog. - A munkahely, gyerekek, tanulás... Hogy ezek mennyire rakódnak. Ha nincsen probléma, akkor megy a dolog. Néha vannak kiakadások, amikor azt mondom, kész, vége, nem bírom. De mindig visszamegyek és mindig segitek." (B., 41 é) 
Az egyik interjúalany esetében a gondozási és munkaterhek együttes eredményeként teljes kimerülés lépett fel, munkahelyi kiégés alakult ki:

„Összességében amikor már a kimerült állapotban voltam, akkor a teljesitményem romlott, de nem önmagában csak a gondozástól” (G., 46 é)

G. egy évre betegszabadságra kényszerült. Bár ez már önmagában jelentős anyagi megterheléssel járt, a felépüléshez szükséges lelki támogatást magán úton finanszírozta, mert az egészségügyi ellátórendszer keretei között nem volt biztosítható a hatékony mentálhigiénés segítség.

\section{A munkahely pozitívuma}

A munka és a gondozás utáni feltöltődés sok esetben szinte teljesen lehetetlenné válik, azonban előfordul, hogy éppen a munkahely lesz pihentető a megterhelő családi-gondozási helyzet után:

"Volt amikor azt érzem, hogy sok a kettö - ott is küzdelem, meg itt is, mindenütt kihívás, és otthon sincs pihenés... de sokszor úgy éreztem, hogy jó, hogy ki tudok lépni itthonról..." (A., 47 é)

Szintén A. említi, hogy a munka pozitívuma a gondozással kapcsolatban a kötött, biztonságot adó napi ritmus:

"Adott egy ritmust is, jobban be voltam szorítva, hogy ekkor ezt csinálom, akkor meg azt." (A., 47 é)

Munkaerő-piaci érdek, hogy a gondozást végző családtagok ne essenek ki a munkából támogatásuk a munkaadó részéről felveti a rugalmasabb munkaidő, és a részmunkaidő lehetőségének biztosítását. Még egyszer hangsúlyozandó, hogy a részmunkaidő vállalása azonban a nem megfelelő összegü ápolási díj mellett komoly anyagi gondokat is jelenthet.

\subsection{A spiritualitás, mint védöfaktor a gondozási helyzetben}

Sokan említik, hogy a nehézségek idején a hitükből, Istennel való kapcsolatukból merítenek erőt - még akkor is, ha kevés idejük marad ennek ápolására:

"Miböl meritek eröt? Az Istennel való kapcsolatból, de nagyon kevés idöm van. Az utóbbi időben nehezen találtam meg. (...) Meg kell találni a formáit, hogy az istenkapcsolat táplálkozzon. Időt adni annak, amikor csak vele vagyok." (A., 47 é)

"Miböl meritek eröt? A hitemböl. A gyerekeimböl, férjemböl, sok idöt töltünk együtt. (...) Problémáim esetén, mi az elsö lépés? Elöször gondolkozom, aztán imádkozom. Ritkán van az, hogy külső segítséghez fordulok. Az imádság sokat segít..." (T., 50 é) 
"Először imádkozni szoktam. Aztán megbeszélem valakivel, meg van, hogy pörgökforgok a helyzet körül, hogy mit is csináljak." (Z., 55 é)

"Csakis az a lelki élet jelentett erőforrást, amit élek." (C., 62 é)

D. kiemeli, hogy az egyházi közösség a gondozottat is támogatja:

"... az egyháztól is jött segítség, elvitték templomba, ha már nem tudott elmenni. Odafigyelnek." (D., 55 é)

B. nem említi erőforrásként a hitet, vagy a vallást, viszont arra a kérdésre, hogy mi ad erőt, az elöretekintést, a célok kitüzését és a pozitív szemléletre való törekvést emeli ki, amelyek a tágabb értelemben vett spiritualitásnak fontos elemei:

"Hát, hogy holnap is kell csinálnom. Meg még vannak céljaim, (...) Néha elkeseredek, akkor magamba borulok, de mindig találok valamit, ami miatt megint eröre kapok." (B., 41 é)

\subsection{Tartózkodás a szociális ellátórendszerrel szemben}

\section{Az ellátás minösége}

A szociális ellátórendszerrel kapcsolatban nagyon kevés a pozitív tapasztalat és az inkább nem állami szolgáltatókhoz köthető, pedig a partneri viszony, az együttmüködés fontos megtartó erő lehetne a gondozási folyamatban. Sokan nem pusztán az információhiány miatt nem fordulnak a házi segítségnyújtás önkormányzatok által biztosított formáihoz, hanem azért sem, mert nem találják megfelelő színvonalúnak az ellátást:

"Egyszer voltunk kapcsolatban. Próbálkoztunk vele, de jobb elfelejteni. (...) Abszolút nem müködött. Nyilvánvaló, hogy ez személyfüggő is. Volt, ahol kiváló tapasztalat volt, azért is fordultunk hozzájuk." (C., 62 é)

Szociális ellátórendszer - társadalmi megítélés - családi kötelezettség

Sokan családi feladatnak tartják a gondozást, szinte szégyellnék, ha nem tudnák ellátni ezt a szerintük elsődlegesen gyermeki kötelezettséget:

"A szociális ellátást anyu nem igényelte, mert hogy itt vagyok én. De hát tényleg, nincs szükség rá. Kialakult a rendszer, az elején féltem, hogy nem jól csinálok valamit, de most már kialakult." (K., 52 é)

"Nem tartottunk rá igényt, amíg így tudunk segíteni." (D., 55 é)

A szociális ellátórendszer és a bizalom

B. arról számol be, hogy a szülők azért nem engedik a szolgálat igénybe vételét, mert félnek, nem bíznak a munkatársakban: 
"Nem. Nem engedik. Mert meglopják, fejbe vágják... Ez már üldözési mánia." (B., 41 é)

Előfordul azonban nagyon pozitív tapasztalat is:

"Nagyon pozitív, a viszony partneri. " (Z., 55 é)

Az időhiány következtében azonban gyakran nem tud kialakulni személyes kapcsolat a családtagokkal. Számos esetben, mivel nincsen találkozási felület, az információk nem áramolnak megfelelően a család és a gondozónők között, aminek akár súlyos következményei is lehetnek a gondozottra nézve - pl. a gondozónő nem értesül időben a gondozásra vonatkozó, legújabb orvosi előírásokról; az idős nem tudja megfelelően tájékoztatni a családot a gondozónővel történt eseményekről, vagy a gondozással kapcsolatos panaszairól, esetleg félelmeiröl.

A gondozók és a család közötti kollegiális, partneri viszony nagyon ritka. Előfordul, hogy a család a gondozás igénylésével úgy érzi, "letudta" saját feladatát, pedig a család szerepe a gondozott mellett, és a gondozási folyamatba való integráltsága a szociális szolgáltatások igénybevételével nem szünhet meg. Előfordul az is, hogy a gondozónők "irányítani" akarják a családtagokat.

A családdal való kapcsolat kiépítésére, ápolására a szociális ellátórendszerben dolgozóknak a tapasztalatok szerint már nincsen kapacitása, pedig a partneri viszony, és az együttmüködés mindkét fél, és a gondozási folyamat szempontjából is gyümölcsöző lenne.

\section{A magyarországi helyzet nemzetközi kitekintésben}

Mivel az ellátórendszerek egyre kevésbé tudják lefedni a gondozási igényeket, újra előtérbe kerül a család, mint természetes gondozási erőforrás. Az informális gondozók által végzett gondozási munka becsült értéke Angliában igen magas: 2015-ben 15,1 millió font volt óránként, ami hetente 2,5 billió fontot jelent - a családi gondozók jelentős terhet vállalnak át az államtól (Buckner és Yeandle 2015). Egy svéd felmérés szerint az informális gondozás óraszáma meghaladja a formális gondozásét (Wimo és mtsai 2017). Coe és munkatársai (2018) rámutatnak, hogy a családi gondozói munka értékének becslésekor nem elég számba venni a gondozási munkaórák értékét. Olyan tényezőket is figyelembe kell venni, mint a gondozás miatt esetleg lecsökkentett professzionális munka - a "kiesett" munkaidő értéke, az "elvesztett" szabadidő értéke, a gondozási folyamat esetleges káros hatása a jövőbeni munkavállalásra, vagy a családi gondozás belső értékei (pl. kötelesség teljesítése). Modelljük 
alapján a családi gondozói munka értéke egy két éves periódusban a gondozott állapotától függően akár 200.000 dollár is lehet.

Az informális, vagyis az egészségügyi és szociális ellátórendszer keretein kívül igénybe vett, nem finanszírozott gondozást főként családtagok biztosítják. Mivel a kutatások szerint a gondozási feladat a családtagok súlyos megterheltségével és egészségkárosodásával járhat, egyre inkább szükségessé válik a gondozók életminőségének mérése, javítása is (Zrubka 2017). A demográfiai folyamatok következtében a gondozás felvállalásakor a gondozók életkora is várhatóan magasabb lesz, így Európa szerte újabb problémákat vethet fel, ha az idősebb gondozottal párhuzamosan ök maguk is gondozottakká válnak majd. (EC 2015)

Annak ellenére, hogy a családtagok jelentős részt vállalnak a gondozási feladatokból, az ellátórendszerek szinte kizárólag a gondozottak ellátására fókuszálnak, a családtagok támogatására nincsenek szolgáltatások. Ahhoz, hogy segíteni tudják az idős hozzátartozót, a családtagoknak is támogatásra van szükségük. A támogatás biztosítása mellett szükséges azonban a családi gondozók partnerként való elismerése az ellátórendszerek részéről (vö. pl. Wolff és Roter 2008, Lavoie és Guberman 2009, UNFPA 2011, Gillick 2013, Szabó 2013, Szabó 2014, Szabó 2015, Roth és mtsai 2015, Fábián 2015, Tróbert 2015, Tróbert és Széman 2016, Patyán 2018). Az elmúlt évtizedekben számos nemzetközi vizsgálat bizonyította, hogy az időseknek segítséget nyújtó családtagok számára a gondozás felvállalása jelentős megterheltséget okoz, amely súlyos következményekkel járhat, akár teljes kiemrüléshez is vezethet. (vö. pl. Ducharme és munkatársai 2001, Pinquart és Sörensen 2003, Schulz és Sherwood 2008, Roth és mtsai 2009; Vitaliano és mtsai 2003, Arican 2016, Do Couto és mtsai 2016, Fekete és mtsai 2017)

A magyar interjúk tükrében látható, hogy a családtagoknak számos nehézséggel kell szembenézniük. A lelki egészségük megőrzéséhez, az életminőség javításához nagy szükség lenne arra, hogy a házi segítségnyújtás keretén belül is igényelni lehessen mentálhigiénés támogatást. A gondozónők kompetenciáját meghaladja, hogy az idős embert vagy a családtagokat lelki nehézségeikben támogassák, illetve megkülönböztessék, hogy mikor lenne szükség szakember segítségére. A házi segítségnyújtás keretein belül jelenleg nem alkalmaznak mentálhigiénés munkatársakat, pedig jelenlétük kulcsfontosságú lenne egyrészt a teljes emberre kiterjedő gondozás megvalósításában, másrészt az interdiszciplináris teammunka megszervezésében. Ezen kívül fontos szerepük lehetne a családdal való kapcsolattartásban is. Gyakran előfordul, hogy az idős és családja kapcsolatát régi konfliktusok terhelik. A mentálhigiénés munkatársak a gondozás hatékonyságát is növelnék, ha támogathatnák a családtagok időshöz való viszonyának javulását. 
Mind a nemzetközi mind a hazai felmérések feltárták, hogy az ellátórendszerekre és informális gondozókra nehezedő nyomás csökkentése érdekében az egészségben eltöltött életévek számának növelése elsődleges feladat, ezért szükségessé válnak a preventív stratégiák, melyek egyben az aktív idősödés alapját képezik. (Walker 2002, UN 2002, WHO 2002/2, INS 2009, Kerekes és Karádi 2013, Semsei 2015, WHO 2016/1,2) Megkerülhetetlen a formális gondozás - tartós gondozási rendszer megerősítése és reformja, ezzel párhuzamosan pedig elengedhetetlen a családtagok gondozási folyamatba való integrálása és a gondozási feladatban való támogatása. Az ellátásban megnő a formális és informális gondozás együttes szerepe, a gondozási folyamatban részt vevők partneri együttmüködésének jelentősége. (Twigg és Atkin 1994, Daatland és Herlofson 2003, Daatland és Lowenstein 2005, Di Rosa és mtsai 2011, Hlebec 2015, Tróbert és Széman 2015, 2016, Patyán 2018)

\section{Záró gondolatok}

Az interjúk elemzésének tükrében hangsúlyozni kell, hogy az ellátórendszerek terheltségének növekedésével a családi erőforrások várhatóan egyre nagyobb szerepet kapnak a tartós gondozásban. Magyarországon a családtagok szociális ellátórendszerrel kapcsolatos feladatait újra kell gondolni. Ehhez elengedhetetlen a családtagok gondozási folyamatba való partneri bevonása, képzése. Emellett mentálhigiénés támogatásuk elsődleges feladattá válik a szolgáltatásfejlesztés terén. A családi gondozók hazai szükségleteinek feltárása, az egészségügy és a szociális szféra összekapcsolása, az integrált tartós gondozási rendszer megvalósításának kezdeményezése, a már bevált jó példák adaptálása sürgető feladat, mely mielőbb további kutatásokat tesz szükségessé.

\section{Hivatkozások}

Arican B, Guney M, Akbal N, Demiral BH, Nadir A, Kokar IK, Dabak MR, Sargin M. (2016) Determining depression level of caregivers providing home healthcare services. North Clin Istanbul, 3: 118-123.

Buckner L, Yeandle S. (2015): Valuing Carers 2015. The rising value of carers's support. Carers UK, 2015. https://www.sheffield.ac.uk/polopoly_fs/1.546409!/file/ValuingCarers-2015.pdf (2018.12.10.)

Coe NB, Skira MM, Larson EB. (2018) A Comprehensive Measure of the Costs of Caring for a Parent: Differences According to Functional Status. JAGS, 66: 2003-2008.

Daatland SO, Herlofson K. (2003) Lost solidarity or changed solidarity: a comparative European view of normative family solidarity. Ageing and society, 23: 537-560. 
Daatland SO, Lowenstein A. (2005) Intergenerational solidarity and the family - welfare state balance. European Journal of Ageing, 2: 174-182.

Di Rosa M, Kofahl Ch, McKee K, Bien B, Lamura G, Prouskas C, Döhner H, Mnich E. (2011) A Typology of Caregiving Situations and Service Use in Family Carers of Older People in Six European Countries. The Eurofamcare Study. Geropsych, 24: 518.

Do Couto AM, De Castro EAB, Caldas CP. (2016) Experiences to be a family caregiver of dependent elderly in the home environment. Rev Rene, 17: 76-85.

Ducharme F, Lebel P, Bergman H. (2001) Vieillissement et soins, l'urgence d'offrir des services de santé intégrés aux familles du XXI siècle. Ruptures, revue transdisciplinaire en santé, 8: 110-121.

EC: The Ageing Report 2015, Economic and budgetary projections for the EU 28 member states 2013 - 2060 European Economy, European Commission, 2015 http://ec.europa.eu/economy_finance/publications/european_economy/2015/pdf/ee3_e $\underline{\text { n.pdf }}(2018.11 .20$.

EK TG: Tartós gondozás az Európai Unióban, Európai Közösségek, Luxembourg 2008 file:///C:/Users/user/Downloads/Brochure_LTCBis_HU_081013.pdf (2018.12.10.)

EUT SzV: Megfelelő szociális védelem az elöregedő társadalomban felmerülő tartós ápolásigondozási igények összefüggésében: A szociális védelemmel foglalkozó bizottság és az Európai Bizottság együttes jelentése. Az Európai Unió Tanácsa, Brüsszel, 2014. http://register.consilium.europa.eu/doc/srv?l=HU\&f=ST\%2010406\%202014\%20INIT (2017.10.15.)

Fábián G. (2015) Interprofesszionális együttmüködési lehetőségek a szociális ellátásban. INDA Interprofesszionális Demencia Alapprogram, 2015. https://inda.info.hu/uploads/dokumentumok/fabian_gergely.pdf (2019.02.20.)

Fekete C, Tough H, Siegrist J, Brinkhof MWG. (2017) Health impact of objective burden, subjective burden and positive aspects of caregiving: an observational study among caregivers in Switzerland BMJ Open, 7: e017369

Gillick MR. (2013) The critical role of caregivers in achieving patientcentered care. JAMA, 310: 575-576.

Hlebec, Valentina (2015): Care arrangements among social home care users in Slovenia, Studia Socioloczne, 2: 75-96.

INS: Idősügyi Nemzeti Stratégia (2009) http://www.parlament.hu/irom38/10500/10500.pdf (2018.10.10.) 
Kerekes Zs, Karádi K. Időskori kognitív változások összefüggései a mindennapi életvezetéssel. In: Kállai J, Kaszás B, Tiringer I (szerk.), Az időskorúak egészségpszichológiája. Medicina Könyvkiadó Zrt, Budapest, 2013:263-288.

Lavoie JP, Guberman N. (2009) Le partenariat professionnel - famille dans les soins aux personnes âgées. Un enjeu de reconnaissance. Lien social et Politiques, 62: 137-148.

Patyán L. (2018) A professzionális és családi gondozók viszonyrendszere az idősek otthoni gondozásában. ELTE TTK, Doktori disszertáció.

Pinquart M, Sörensen S. (2003) Differences between caregivers and noncaregivers in psychological health and physical health: A meta-analysis. Psychology and Aging, 18: 250-267.

Roth DL, Fredman L, Haley WE. (2015) Informal Caregiving and Its Impact on Health: A Reappraisal From Population-Based Studies. The Gerontologist, 55: 309-319.

Roth DL, Perkins M, Wadley VG, Temple EM, Haley WE. (2009) Family caregiving and emotional strain: Associations with quality of life in a large national sample of middleaged and older adults. Quality of Life Research, 18: 679-688.

Schulmann K, Leichsenring K, Casanova G, Ciuca V, Corches L, Genta M, Grigaliüniené Z, Kucsera Cs, Matei A, Maattanen N, Naegele G, Paat-Ahi G, Pirciog S, Principi A, Rodrigues L, Rodrigues R, Sanduleasa B, Shulze S, Reichert M, Széman Zs, Wall K. (2014) MoPAct Mobilising the Potential of Active Ageing in Europe Social support and long term care in EU care regimes. WP8. Overview report http://mopact.group.shef.ac.uk/wp-content/uploads/2013/10/Social-support-overviewreport.pdf (2018.10.12.)

Schulmann K, Leichsenring K, Casanova G, Ciucă V, Ghența M, Gouveia R, Lamura G, Matei A, Mladen L, Naegele G, Oja I, Paat-Ahi G, Pîrciog S, Reichert M, Schulze S, Széman Zs, Tróbert AM. A qualitative inventory of the key drivers of social innovation in social support and long term care (QUALIND), Final Report. Vienna, 2015 http://mopact.group.shef.ac.uk/wp-content/uploads/2013/10/D8.3-A-qualitativeinventory-of-the-key-drivers.pdf $(2018.10 .12$.

Schulz R, Sherwood P. (2008) Physical and mental health effects of family caregiving. The American Journal of Nursing, 108: 23-27.

Semsei I. (2015) Demencia okozta társadalmi kihívások - demenciával együtt élő társadalom. INDA Interprofesszionális Demencia Alapprogram, 2015. https://inda.info.hu/uploads/dokumentumok/semsei_imre.pdf (2019.01.20.)

Szabó L. (2013) Idősellátás kérdőjelekkel. Esély, 24: 87-97. 
Szabó L. (2014) A professzionális és informális segítők szerepe az idősek otthoni ellátásában. Esély, 25: 79-93.

Szabó L. (2015) Gondozó családok támogatása. INDA Interprofesszionális Demencia Alapprogram, 2015. https://inda.info.hu/uploads/dokumentumok/szabo_lajos.pdf (2019.02.20.)

Széman Zs, Pottyondy P. (2006) Idősek otthon. Megszokott környezetben, nagyobb biztonsággal. Magyar Máltai Szeretetszolgálat Egyesület - MTA Szociológiai Kutatóintézet, Budapest, 2006

Széman Zs, Tróbert AM. (2017/1) A szociális innováció lehetőségei a tartós idősgondozásban. Esély, 28: 45-62.

Széman Zs, Tróbert AM. (2017/2) Social innovation in the provision of services in long term care. European Journal of Mental Health, 12: 204-217.

Tróbert AM. (2015) Az idős hozzátartozót ápolók támogatásának jelentősége. Esély, 26: 8594.

Tróbert AM, Asztalos B, Széman Zs. (2018) Az e-learning képzés szerepe a formális és informális idősgondozók támogatásában In: Fodorné Tóth K (szerk.) A felsőoktatási lifelong learning társadalmi és gazdasági haszna: kutatás - fejlesztés - innováció: Social And Economic Benefits Of University Lifelong Learning: Research Development And Innovation. MELLearN Felsőoktatási Hálózat az életen át tartó tanulásért Egyesület, Debrecen, 2018: 256-271.

Tróbert AM, Széman Zs. (2015) Szociális innováció a tartós idősgondozásban Magyarországi összefoglaló beszámoló. Kézirat, MTA

Tróbert AM, Széman Zs. (2016) Kiegészítő elemzés a MoPAct WP8 T3 magyar fókuszcsoportjában felmerült problémafelvetéshez. Kézirat, MTA

Tróbert AM, Széman Zs. (2018) Háziorvosok és idősellátás egy kérdőíves kutatás tükrében. Orv Hetil, 159: 312-319.

Twigg J, Atkin K. Carers perceived: Policy and practice in informal care. Open University Press Buckingham 1994

UN: Political Declaration and Madrid International Plan of Action on ageing. United Nations, New York, 2002

UNFPA: Overview of Available Policies and Legislation, Data and Research, and Institutional Arrangements Relating To Older Persons - Progress Since Madrid. UNFPA - HelpAge International, 2011 https://www.unfpa.org/sites/default/files/pubpdf/Older_Persons_Report.pdf (2018.11.20.) 
Vitaliano PP, Zhang J, Scanlon JM. (2003). Is caregiving hazardous to one's health? A metaanalysis. Psychological Bulletin, 129: 946-972.

Walker A. (2002) A strategy for active ageing. International Social Security Review, 55: 121139.

WHO (2002/2) Active Ageing: A Policy Framework. WHO, 2002 https://www.who.int/ageing/publications/active_ageing/en/ (2018.12.10.)

WHO (2016/1) Rapport mondiale sur le vieillissement, WHO, 2016 https://apps.who.int/iris/bitstream/handle/10665/206556/9789240694842_fre.pdf (2018.11.20.)

WHO (2016/2) Action multisectorielle pour une approche du vieillissement en bonne santé prenant en compte toutes les étapes de la vie : projet de stratégie et de plan d'action mondiaux sur le vieillissement et la santé. WHO, 2016/2, http://www.who.int/iris/handle/10665/250847 (2018.11.20.)

Wimo A, Elmståhl S, Fratiglioni L, Sjölund BM, Sköldunger A, Fagerström C, Berglund J, Lagergren M. (2017) Formal and informalcare of community-livingolderpeople: a population-basedstudyfromtheswedishnationalstudyonaging and care. J Nutr Health Aging, 21: 17-25.

Wolff JL, Roter DL. (2008) Hidden in plain sight: medical visit companions as a resource for vulnerable older adults. Archives of Internal Medicine, 168: 1409-1415.

Zrubka Zs. (2017) Az informális ellátás mérése és egészség-gazdaságtani értékelése. Orv Hetil, 158: 1363-1372. 